\title{
Topical Finasteride versus Topical Spironolactone in the Treatment of Androgenetic Alopecia
}

\author{
AYMAN E. YOUSEF, M.D.*; AHMED S. ABDELSHAFY, M.D.* and MOUSA A.S. ALMABROUK, M.Sc.** \\ The Department of Dermatology and Venereology, Faculty of Medicine, Zagazig University, Egypt* and \\ Tripoli University, Libya**
}

\begin{abstract}
Background: Androgenetic Alopecia (AGA) is a nonscarring alopecia that affects both males and females. It is characterized by a progressive miniaturization of hair follicles with a characteristic pattern distribution in genetically predisposed men and women. Topical finasteride is being investigated as a new treatment for AGA with fewer side effects than oral finasteride. Topical Spironolactone is the most commonly used off-label anti-androgen for the treatment of AGA. In the treatment of AGA, it acts by decreasing the production and competitively blocking the androgen receptor in the target tissue.
\end{abstract}

Aim of Study: The aim of this study was to evaluate the role and compare the effect of topical finasteride and topical spironolactone in the treatment of (AGA).

Patients and Methods: After meeting inclusion and exclusion criteria and diagnosis of AGA was clinically established by the characteristic distribution of frontal and vertex hair in males and the Christmas tree pattern of diffuse hair loss at middle hairline in females. It was dermosopically established by the characteristic hair shaft thickness heterogeneity, peripilar brown depressions (peripilar signs) and focal atrichia and also folliscope established for hair density. Cases included in this study had Norwad-Hamilton Scale types I to VII for men and Ebling Scale types I to IV for women.

Result: Our study shows that a topical spironolactone is better than topical finasteride in male and female group.

Conclusion: In this study, topical finasteride and topical spironolactone are good options for management of androgenic alopecia but topical spironolactone is better than topical finasteride with few side effects when compared to oral administration.

Key Words: Alopecia-Finasteride-Spironolactone.

\section{Introduction}

ANDROGENETIC Alopecia (AGA) is a slowly progressive form of hair loss which begins after the onset of puberty. It occurs due to underlying

Correspondence to: Dr. Mousa A.S. Almabrouk, E-Mail: musashanb@hotmail.com susceptibility of hair follicles to androgenic miniaturization. It is the most common cause of hair loss that affects up to $70 \%$ of men and $40 \%$ of women at some point in their lifetime. Men typically present with hairline recession at the temples and vertex balding while women present with normally diffusely thin hair over the top of their scalps [1].

Topical Finasteride has been specifically formulated to function by means of local application to the scalp. It has been designed to significantly reduce the body's direct exposure to the drug and thus minimize any potentially adverse effects that may arise from such exposure [2].

Topically applied Spironolactone does not have the same side effects as the orally ingested Aldactone. In fact, the topically applied Spironolactone works so well that it is often used as a one-two punch combination with Propecia, it also decreases testosterone production in the adrenal gland by depleting microsomal cytochrome $\mathrm{p} 450$ and by affecting the cytochrome p450-dependent enzyme 17a-hydroxylase and desmolase, as well as competitive inhibitor of the androgen receptor blocking the androgen action on the target tissues [3] .

\section{Aim of the work:}

The aim of this study was to evaluate the role and compare the effect of topical finasteride and topical spironolactone in the treatment of (AGA).

\section{Patients and Methods}

This is an interventional study was carried out at the outpatient clinic of Dermatology, Venereology and Andrology Department, Faculty of Medicine, Zagazig University Hospitals in the period from June 2018 till December 2018. Thirty two males 
and females patients of different age, duration and grades of AGA were be included in our study.

The diagnosis of AGA was clinically established by the characteristic distribution of frontal and vertex hair in males and the Christmas tree pattern of diffuse hair loss at middle hairline in females. It was dermosopically established by the characteristic hair shaft thickness heterogeneity, peripilar brown depressions (peripilar signs) and focal atrichia and also folliscope established for hair density. Cases included in this study had NorwadHamilton Scale types I to VII for men and Ebling Scale types I to IV for women.

\section{Results}

A total of 32 participants were enrolled in our study included sixteen patients ( 8 males and 8 females) aged 20-60 years. They were treated with topical finasteride solution $0.1 \%$ for six months and sixteen patients ( 8 males and 8 females) aged $20-60$ years. They were treated with topical Spironolactone solution 5\% for six months.

Table (1) showed that there was no statistically significant difference in family history, side effects and male patients' satisfaction between male using Finasteride and Spironolactone groups. Table (2), showed that there was no statistically significant difference in trichoscopy data baseline and after 6 months between males using Finasteride and Spironolactone groups (Table 3), showed that there was no statistically significant difference in family history, side effects and female patients' satisfaction between female using Finasteride and Spironolactone groups.

Table (4) showed that there was no statistically significant difference in trichoscopy data baseline and after 6 months between females using Finasteride and Spironolactone group.

Table (1): Comparing family history, side effects and patients satisfaction and between the groups using Finasteride and Spironolactone group in male patients.

\begin{tabular}{|c|c|c|c|c|c|c|}
\hline \multirow[t]{2}{*}{ Variable } & \multicolumn{2}{|c|}{$\begin{array}{l}\text { Finasteride } \\
\text { group }\end{array}$} & \multicolumn{2}{|c|}{$\begin{array}{l}\text { Spironolactone } \\
\text { group }\end{array}$} & \multirow{2}{*}{$x^{2}$} & \multirow{2}{*}{$p$-value } \\
\hline & No. (8) & $\%$ & No. (8) & $\%$ & & \\
\hline \multicolumn{7}{|l|}{ Family history: } \\
\hline Negative & 2.0 & 25.0 & 1.0 & 12.5 & FET & 0.5 \\
\hline Positive & 6.0 & 75.0 & 7.0 & 87.5 & & \\
\hline \multicolumn{7}{|l|}{ Side effects: } \\
\hline No & 5.0 & 62.5 & 6.0 & 75.0 & FET & 0.5 \\
\hline Yes & 3.0 & 37.5 & 2.0 & 25.0 & & \\
\hline \multicolumn{7}{|c|}{ Patients satisfaction: } \\
\hline Not satisfied & 3.0 & 37.5 & 4.0 & 50.0 & FET & 0.5 \\
\hline Satisfied & 4.0 & 50.0 & 4.0 & 50.0 & & \\
\hline Very satisfied & 1.0 & 12.5 & 0.0 & 0.00 & & \\
\hline
\end{tabular}

In this table, there was no statistically significant difference in family history, side effects and male patients' satisfaction between male using Finasteride and Spironolactone groups.

Table (2): Comparing trichoscopy baseline and after 6 months between the group using Finasteride and Spironolactone group in male patients.

\begin{tabular}{|c|c|c|c|c|c|c|}
\hline \multirow[t]{2}{*}{ Variable } & \multicolumn{2}{|c|}{$\begin{array}{l}\text { Finasteride } \\
\text { group }\end{array}$} & \multicolumn{2}{|c|}{$\begin{array}{l}\text { Spironolactone } \\
\text { group }\end{array}$} & \multirow{2}{*}{$x^{2}$} & \multirow{2}{*}{$\begin{array}{c}p- \\
\text { value }\end{array}$} \\
\hline & No. (8) & $\%$ & No. (8) & $\%$ & & \\
\hline \multicolumn{7}{|c|}{$\begin{array}{l}\text { Hair diameter diversity } \\
\text { baseline: }\end{array}$} \\
\hline No & 0.0 & 00.0 & 0.0 & 00.0 & FET & 0.1 \\
\hline Yes & 8.0 & 100.0 & 8.0 & 100.0 & & \\
\hline \multicolumn{7}{|c|}{$\begin{array}{l}\text { Perpilar sign after } \\
\text { baseline: }\end{array}$} \\
\hline No & 0.0 & 00.0 & 0.0 & 00.0 & FET & 0.1 \\
\hline Yes & 8.0 & 100.0 & 8.0 & 100.0 & & \\
\hline \multicolumn{7}{|c|}{ Focal atricha baseline: } \\
\hline No & 1.0 & 12.5 & 0.0 & 00.0 & FET & 0.3 \\
\hline Yes & 7.0 & 87.5 & 8.0 & 100.0 & & \\
\hline \multicolumn{7}{|c|}{$\begin{array}{l}\text { Hair diameter diversity } \\
\text { after } 6 \text { months: }\end{array}$} \\
\hline No & 1.0 & 12.5 & 0.0 & 00.0 & FET & 0.1 \\
\hline Yes & 7.0 & 87.5 & 8.0 & 100.0 & & \\
\hline \multicolumn{7}{|c|}{$\begin{array}{l}\text { Perpilar sign after } 6 \\
\text { months: }\end{array}$} \\
\hline No & 2.0 & 25.0 & 1.0 & 12.5 & FET & 0.5 \\
\hline Yes & 6.0 & 75.0 & 7.0 & 87.5 & & \\
\hline \multicolumn{7}{|c|}{$\begin{array}{l}\text { Focal atricha after } 6 \\
\text { months: }\end{array}$} \\
\hline No & 5.0 & 62.5 & 4.0 & 50.0 & FET & 0.6 \\
\hline Yes & 3.0 & 37.5 & 4.0 & 50.0 & & \\
\hline
\end{tabular}

Table (3): Comparing family history, side effects and patients satisfaction and between the group using Finasteride and the group using Spironolactone in female patients.

\begin{tabular}{lcccccc}
\hline \multirow{2}{*}{ Variable } & $\begin{array}{c}\text { Finasteride } \\
\text { group }\end{array}$ & $\begin{array}{c}\text { Spironolactone } \\
\text { group }\end{array}$ & X & $\begin{array}{c}p \text { - } \\
\text { value }\end{array}$ \\
\cline { 2 - 4 } & No. (8) & $\%$ & No. (8) & $\%$ & & \\
\hline Family history: & & & & & & \\
$\quad$ Negative & 1.0 & 12.5 & 2.0 & 25.0 & FET & 0.5 \\
$\quad$ Positive & 7.0 & 87.5 & 6.0 & 75.0 & & \\
Side effects: & & & & & & \\
$\quad$ No & 7.0 & 87.5 & 6.0 & 75.0 & FET & 0.5 \\
$\quad$ Yes & 1.0 & 12.5 & 2.0 & 25.0 & & \\
Patients satisfaction: & & & & & & \\
$\quad$ No & 2.0 & 25.0 & 0.0 & 00.0 & 2.3 & 0.3 \\
$\quad$ Satisfied & 5.0 & 62.5 & 7.0 & 87.5 & & \\
$\quad$ Very satisfied & 1.0 & 12.5 & 1.0 & 12.5 & & \\
\hline
\end{tabular}

In this table, there was no statistically significant difference in family history, side effects and female patients' satisfaction between female using Finasteride and Spironolactone groups. 
Table (4): Comparing trichoscopy baseline and after 6 months between the group using Finasteride and Spironolactone group in female patients.

\begin{tabular}{|c|c|c|c|c|c|c|}
\hline \multirow[t]{2}{*}{ Variable } & \multicolumn{2}{|c|}{$\begin{array}{l}\text { Finasteride } \\
\text { group }\end{array}$} & \multicolumn{2}{|c|}{$\begin{array}{l}\text { Spironolactone } \\
\text { group }\end{array}$} & \multirow[t]{2}{*}{$\chi^{2}$} & \multirow{2}{*}{$\begin{array}{c}p- \\
\text { value }\end{array}$} \\
\hline & \multicolumn{2}{|c|}{ No. (8) \% } & No. (8) & $\%$ & & \\
\hline \multicolumn{7}{|c|}{$\begin{array}{l}\text { Hair diameter diversity } \\
\text { baseline: }\end{array}$} \\
\hline No & 0.0 & 0.00 & 0.0 & 0.00 & FET & 1 \\
\hline Yes & 8.0 & 100.0 & 8.0 & 100.0 & & \\
\hline \multicolumn{7}{|c|}{ Perpilar sign baseline: } \\
\hline No & 0.0 & 0.00 & 1.0 & 12.5 & FET & 1 \\
\hline Yes & 8.0 & 100.0 & 7.0 & 87.5 & & \\
\hline \multicolumn{7}{|c|}{ Focal atricha baseline: } \\
\hline Nao & 1.0 & 12.5 & 1.0 & 12.5 & FET & 1 \\
\hline Yes & 7.0 & 87.5 & 7.0 & 87.5 & & \\
\hline \multicolumn{7}{|c|}{ Hair diameter diversity after } \\
\hline No & 1.0 & 12.5 & 0.0 & 00.0 & FET & 1 \\
\hline Yes & 7.0 & 87.5 & 8.0 & 100.0 & & \\
\hline \multicolumn{7}{|c|}{ Perpilar sign after 6 months: } \\
\hline No & 3.0 & 37.5 & 4.0 & 50.0 & FET & 0.5 \\
\hline Yes & 5.0 & 62.5 & 4.0 & 50.0 & & \\
\hline \multicolumn{7}{|c|}{ Focal atricha after 6 months: } \\
\hline No & 6.0 & 75.0 & 8.0 & 100.0 & FET & 0.4 \\
\hline Yes & 2.0 & 25.0 & 0.0 & 0.00 & & \\
\hline
\end{tabular}

\section{Discussion}

The primary outcome of the study had to be change in hair density and had to provide an effect size such as mean and a measure of variance (standard deviation, standard error, or $95 \%$ confidence interval). The age of the study group (males and females) $(33.7 \pm 6.4)$ ranged from ( 23 to 47$)$ years and $(50.0 \%)$ of them were females and $(50.0 \%)$ were males. No statistically significant difference in family history, side effects and patients satisfaction between group using finasteride and spironolactone groups. In this study, the commonest Hamilton Norwoods scale for males used finas-teride baseline was grade III $(50.0 \%)$ followed by grade II $(25.0 \%)$, grade IVa and V (12.5\%) while commonest Hamilton Norwoods scale for males after 6 months was grade II $(62.5 \%)$ followed by grade III, IIa and IV (12.5\%). In this study, the commonest Hamilton Norwoods scale for males used Spironolactone baseline was grade II and V (25.0\%) followed by grade I, IIa, IV and VI and VI (12.5\%) while commonest Hamilton Norwoods scale for males after 6 months was grade II and V (25.5\%) followed by grade III, IIa and IV (12.5\%). No significant statistically significant difference in Ha-milton Norwoods scale baseline and after 6 months between male using finasteride and spironolactone in this study, the commonest Ebling scale for females used finasteride baseline was grade II $(50.0 \%)$ followed by grade III $(25.0 \%)$ while commonest Ebling scale for males after 6 months was grade I (50\%) followed by grade II (25\%). In this study, the commonest Ebling scale for females used Spironolactone baseline was grade I and III (37.5\%) followed by grade II and IV (12.5\%) while commonest Ebling scale for males after 6 months was grade I (50\%) followed by grade II, (25.0\%) no significant statistically significant difference in Ebling scale baseline and after 6 months between female using finasteride and spironolactone. Our study shows that decrease in signs of androgenic alopecia: (Hair diameter diversity, peripilar sign and focal atricha), (100.0\%) of the male finasteide group had hair diameter diversity baseline while $(87.5 \%)$ had hair diameter diversity after 6 months treatment. Regarding perpilar sign, (100\%) of the male group had perpilar sign baseline and $(75.0 \%)$ had perpilar sign after 6 months treatment. Concerning focal atricha, $(87.5 \%)$ of the female group had focal atricha baseline while only $(37.5 \%)$ had focal atricha after 6 months treatment. Our study shows that $(100.0 \%)$ of the male spironolactone group had hair diameter diversity baseline while (100.0\%) had hair diameter diversity after 6 months treatment. Regarding perpilar sign, $(100.0 \%)$ of the male group had perpilar sign baseline and (100.0\%) had perpilar sign after 6 months treatment. Concerning focal atricha, $(100.0 \%)$ of the female group had focal atricha baseline while only $(50.0 \%)$ had focal atricha after 6months treatment. No significant statistically significant difference in Trich-oscopy data baseline and after 6 months between male using finasteride and spironolactone. Our study shows that $(100.0 \%)$ of the female finasteide group had hair diameter diversity baseline while $(87.5 \%)$ had hair diameter diversity after 6 months treatment. Regarding perpilar sign, (100\%) of the male group had perpilar sign baseline and (62.5\%) had perpilar sign after 6 months treatment. Concerning focal atricha, $(87.5 \%)$ of the female group had focal atricha baseline while only $(25.0 \%)$ had focal atricha after 6 months treatment. Our study shows that $(100.0 \%)$ of the female spironolactone group had hair diameter diversity baseline while (100.0\%) had hair diameter diversity after 6 months treatment. Regarding perpilar sign, (87.5\%) of the male group had perpilar sign baseline and (50.0\%) had perpilar sign after 6 months treatment. Concerning focal atricha, $(87.5 \%)$ of the female group had focal atricha baseline while only $(00.0 \%)$ had focal atricha after 6 months treatment. No significant statistically significant difference in Trichoscopy data baseline and after 6 months between female using finasteride and spironolactone. (50.0\%) of the male group were satisfied, $(6.2 \%)$ were very 
satisfied and $(43 \%)$ not satisfied after treatment. In this study, the commonest Hamilton Norwoods scale for males used finasteride and spironolactone baseline was grade III (37.5\%) followed by grade II and V (18.8\%) while commonest Hamilton Norwoods scale for males after 6 months was grade II (43.8\%) followed by grade IV and V (12.5\%) No significant statistically significant difference in between Hamliton Noorwoods scale for male's baseline and after 6 months using finasteride and spironolactone. In this study, (100.0\%) of the male group had hair diameter diversity baseline while (93.8\%) had hair diameter diversity after 6 months treatment. Regarding perpilar sign, all males $(100.0 \%)$ had perpilar sign baseline and $(81.2 \%)$ had perpilar sign after 6 months treatment. Concerning focal atricha, $(93.8 \%)$ of the male group had focal atricha baseline while only $(43.8 \%)$ had focal atricha after 6 months treatment seventy five percent of the female group were satisfied, twelve and half percent were very satisfied and tweleve and half percent not satisfied after treatment. In the this study, Ebling scale (I-IV) of androgenic alopecia for females: The commonest Ebling scale for females baseline was grade II $(43.8 \%)$ followed by grade IV (25.0\%) while commonest Ebling scale for females after 6 months was grade I $(50.0 \%)$ followed by grade II $(25.0 \%)$ there was statistically significant difference between Ebling scale for females' baseline and after 6 months in female patients. Our study shows that $(100.0 \%)$ of the female group had hair diameter diversity baseline while $(93.8 \%)$ had hair diameter diversity after 6 months treatment. Regarding perpilar sign, (93.8\%) of the female group had perpilar sign baseline and $(56.3 \%)$ had perpilar sign after 6 months treatment. Concerning focal atricha, $(87.5 \%)$ of the fe-male group had focal atricha baseline while only $(12.5 \%)$ had focal atricha after 6 months treatment.

In our study $68.7 \%$ of the male group had increased hair count after 6 months treatment and $(87.5 \%)$ of the female group had increased hair count after 6 months treatment. There was no statistically significant difference between male and female in percent of increased hair count after treatment.

There was no statistically significant difference between hair diameter diversity baseline and after 6 months in female patients. There was highly statistically significant difference between focal atricha baseline and after 6 months in female patients. There was statistically significant difference between Perpilar sign baseline and after 6 months in female patients.
Our study shows that topical spironolactone is better than topical finasteride in male and female group.

Topical spironolactone and topical finasteride in female group were better than topical spironolactone and topical finasteride in male group.

Result is in Mazzarella et al., 1997 for evaluating topical finasteride for pattern hair loss were found, and only 1 study involved women. Finasteride $0.005 \%$ (in a base of ethanol, propylene glycol, and water) was studied in 52 patients with androgenetic alopecia, including 24 women (mean age 33 years, range $23-38$ years) in a 16-month single-blind, placebo-controlled trial. Treatment consisted of $1 \mathrm{~mL}$ of solution applied twice daily to balding areas. There was no response to treatment in the first 3 months, however, by 6 months there were statistically significant differences in hair density and hair loss compared to placebo. Although the results were not stratified by sex, by the end of the study all treated patients had slight to marked reduction of balding areas and all reported perceived benefit, rating their treatment moderately $(27 \%)$ or highly effective $(73 \%)$. Treatment was well-tolerated.

With no report of local or systemic side effects, and no effect on plasma testosterone or dihydrotestosterone were observed [4].

These results were in agreement with study done by Charuwichitratana et al., 2003) using $0.1 \%$ finasteride solution and also in agreement with another study done by Sitticharoenchai, 2006). Using $0.5 \%$ finasteride solution revealed superior efficacy to placebo $[\mathbf{5 , 6 ]}$.

Also a good response to topical finasteride was confirmed a systematic seven articles were included. In all studies, there was significant increase in hair density and decrease in the rate of hair loss, increase total and terminal hair counts, and positive hair growth assessment with topical FNS. Both scalp and plasma DHT significantly decreased with application of topical FNS; no changes in serum testosterone were noted. The authors concluded that, preliminary results on the use of topical FNS are limited, but safe and promising [7].

A randomized, double-blind, comparative study to determine the efficacy and safety of $3 \%$ minoxidil versus combined $3 \%$ minoxidil/and $0.1 \%$ finasteride in male pattern hair loss showed significantly greater improvement in the $3 \%$ minoxidil/ and $0.1 \%$ finasteride group than the minoxidil group [8]. 
Moreover, application of $1 \mathrm{ml}$ once daily of topical finasteride resulted in a more constant response in terms of scalp DHT inhibition, than the 1-mg of finasteride tablet administered once daily, taking into consideration the possible intersubject variability derived from various factors, such as the different grade of baldness [9]

Spironolactone arrests hair loss progression with a favourable long-term safety profile [10]

\section{Conclusion:}

Based on the results obtained in the present study, we can conclude topical spironolactone is better than topical finasteride in the treatment of androgenic alopecia in male and female group. More studies with a large number of patients and prolonged follow-up are needed to confirm this and to compare the efficacy of topical finasteride versus topical spironolactone in the management of androgenic alopecia.

Topical finasteride and topical spironolactone are good options for management of androgenic alopecia with few side effects when compared to oral administration.

\section{References}

1- LEAVITT M.: Understanding and management of female pattern alopecia. Facial Plastic Surgery, Nov., 24 (04): 414-27, 2008

2- CASERINI M., RADICIONI M., LEURATTI C., ANNONI O. and PALMIERI R.: A novel finasteride $0.25 \%$ topical solution for androgenetic alopecia: Pharmacokinetics and effects on plasma androgen levels in healthy male volunteers. Int. J. Clin. Pharmacol. Ther., Oct. 1; 52 (10): 842-9, 2014.
3- RATHNAYAKE D. and SINCLAIR R.: Innovative use of spironolactone as an antiandrogen in the treatment of female pattern hair loss. Dermatologic Clinics. Jul. 1; 28 (3): 611-8, 2010.

4- MAZZARELLA G.F., LOCONSOLE G.F., CAMMISA G.A., MASTROLONARDO G.M. and VENA G.A.: Topical finasteride in the treatment of androgenic alopecia. Preliminary evaluations after a 16-month therapy course Journal of dermatological treatment, Jan. 1; 8 (3): 18992, 1997.

5- CHARUWICHITRATANA S., KRISDAPONG P., SUMETHIWIT R. and TUCHINDA C.: Randomized doubleblind placebo controlled trial in the treatment of male androgenetic alopecia with $0.1 \%$ finasteride solution. Jpn. J. Dermatol., 113: 881, 2003.

6- SITTICHAROENCHAI P.: Clinical evaluation of topical formulation of finasteride in male androgenetic alopecia. Bangkok: Chulalongkom University, 2006.

7- LEE S.W., JUHASZ M., MOBASHER P., EKELEM C and MESINKOVSKA N.A.: A systematic review of topical finasteride in the treatment of androgenetic alopecia in men and women. Journal of drugs in dermatology: JDD, Apr. 1; 17 (4): 457, 2018.

8- HU R., XU F., SHENG Y., QI S., HAN Y., MIAO Y., et al.: Combined treatment with oral finasteride and topical minoxidil in male androgenetic alopecia: A randomized and comparative study in Chinese patients. Dermatologic therapy, Sep., 28 (5): 303-8, 2015.

9- CASERINI M., RADICIONI M., LEURATTI C., TERRAGNI E., IORIZZO M. and PALMIERI R.: Effects of a novel finasteride $0.25 \%$ topical solution on scalp and serum dihydrotestosterone in healthy men with androgenetic alopecia. International journal of clinical pharmacology and therapeutics, 54 (1): 19, 2016.

10- LEVY L.L. and EMER J.J.: Female pattern alopecia: Current perspectives. International journal of women's health, 5: 541, 2013. 


\section{فيناسترايد الموضعى مقابل سبايرونولاكتون الموضعى المورى فى علاج الصلع الوراثى}

الصلع الوداثى يتميز بتصغير تدريجى لشعر فروة الرآس وبنمط معين، وهو السبب الآكثر شيوعاً لفقدان الشعر عند البالغين الفين. وتعتبر آسبابه

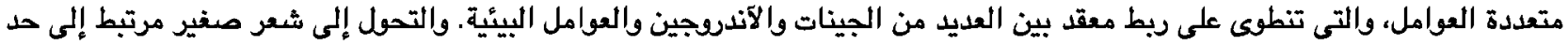
كبير بالآندروجين.

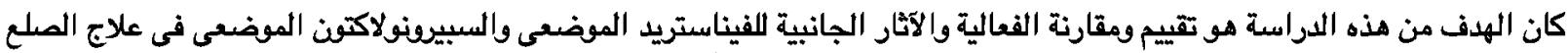

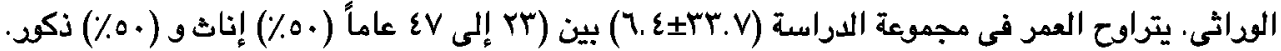

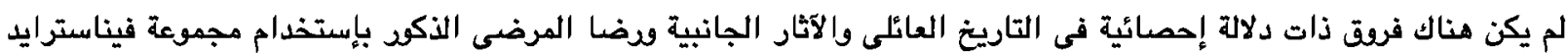

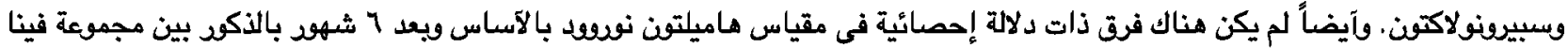
ستريد وسبيرونولاكتون.

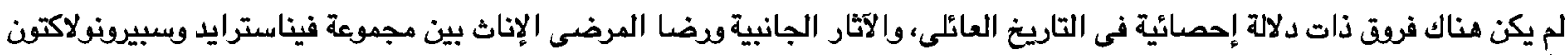

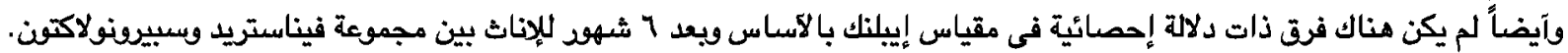
فيناسترايد الموضعى وسبيرونولاكتون الموضعى كالامما علاج جيد الملع الوراثى وبدون مضاعفات جانبية خطيرة ونوصى بإطالة مدة العلاج الحصول على نتائج آفضل. 